\title{
ANNOUNCEMENTS · MITTEILUNGEN
}

The XIth International Congress of Nutrition sponsored by the International Union of Nutritional Sciences (IUNS) will be held Aug. 27 - Sept. 1, 1978, at the Riotur International Center in Rio de Janeiro, Brazil.

The main objective of the Congress will be to discuss "The practical utilization of available multisectorial technical and scientific knowledge to solve food and nutritional problems".

Chairman of the executive committee: Walter J. Santos

Mailing address: XI Congresso Internaçional de Nutrição,

Sociedade Brasileira de Nutrição

Avenida Churchill, $94-6$. andar $-\mathrm{s} / 615$

20.000 - Rio de Janeiro - RJ - Brazil

Für den Inhalt verantwortlich: Prof. Dr. Dr. K. Lang, Schwarzwaldstr. 71, 7812 Bad

Krozingen - Dr. Dietrich Steinkopff Verlag, Postfach 111008 , Saalbaustr. 12, 6100 Darmstadt 11 - Satz und Druck: Ungeheuer + Uimer KG GmbH + Co, Körnerstraße 14-18, 7140 Ludwigsburg. 